\title{
Implementation of the right to social security in Nigeria
}

\author{
Kehinde Anifalaje* \\ Lecturer, Department of Commercial and Industrial Law, University of Ibadan, \\ Oyo State, Nigeria
}

\section{Summary}

The article examines the constitutional provision on the justiciability of the right to social security as well as other legislation on social security in Nigeria with a view to determining the extent to which the right is actualised in the country. It is argued that, apart from the issue of the prima facie non-justiciability of the right, the various Nigerian laws on social security are inadequate in their content and scope of application. The article further argues that the various national/state programmes on social protection are not stricto sensu social security schemes as they are not anchored in any legislation and do not create any enforceable rights for citizens. It concludes that there is a need for Nigerian policy makers to demonstrate greater commitment to the due implementation of this right in Nigeria by enacting an all-encompassing social security law and making appropriate budgetary provision for the sector.

Key words: social security; right; justiciability; Nigerian Constitution 1999

\section{Introduction}

Guaranteeing to everyone the right to social security is pivotal if we must significantly reduce poverty in society and enhance the socioeconomic development of a nation. Social security refers to the schedule of reliefs, benefits, entitlements and facilities that are accessible to and obtainable by citizens in any given community in terms of the relevant municipal laws, and under the auspices and control of the state. These are usually deployed as viable and formidable palliatives to the endless social and economic risks to which the strong and young, as well as the feeble and old members of the community are exposed. Social security is defined as

* LLB (Lagos) BL LLM (Ibadan) PhD (Ibadan); kennyanif@gmail.com 
the social protection, organised collective protection of the individual against want, poverty, destitution, disease and idleness, which may be thrust upon him by the varied hazards and vicissitudes of social life, notably loss or suspension of income or means of sustenance resulting from sickness, maternity, accident injury, invalidity, old age, death of breadwinner or unemployment. ${ }^{1}$

The concept of social security is rooted in welfarism, which is generally thought of as an application of social justice which entails that all persons, apart from their conduct or choice, have a claim to an equal share in all those things (advantages) which are generally desired and are in fact conducive to their wellbeing. ${ }^{2}$ This principle is not identical to the demand for equal treatment of all persons; it rather requires preferential treatment for the underprivileged who lack advantages possessed by others. ${ }^{3}$

The relevance of social security in modern societies cannot be under-estimated in view of its enormous benefits. In communities where there is in existence a viable and functional social security scheme, it has served as goal-oriented programmes, such as the alleviation of want and sub-standard living. Also, on a general note, social security has served as a fixed, firm and effective programme which is not only viable, but which impact is deeply felt by all. Furthermore, in all communities, albeit to a larger extent in more developed communities, social security has served as a socioeconomic programme with positive cyclical effects, such as the enhancement of a high standard of living and, ultimately, life expectancy, the promotion of good life and the eradication of squalor and other social menaces, such as corruption and other criminal activities.

Moreover, social security is now universally recognised as a human right. This is attested to by the number of international instruments that have affirmed the right as one of the socio-economic rights to which every human being is entitled. Social security was first established as a basic human right in 1944 in the Declaration of Philadelphia of the International Labour Organisation (ILO), wherein the International Labour Conference recognised the ILO's obligation concerning 'the extension of social security measures to provide a basic income to all in need of such protection and comprehensive medical care'. This Declaration was pivotal to the ILO Income Security Recommendation 67 of $1944^{4}$ and the subsequent drafting of the ILO Social Security (Minimum Standards) Convention 102 of 1952. The right to social security is also given recognition in the Universal

BO Nwabueze Social security in Nigeria (1989) 1.

AM Honore 'Social justice' in RS Summer (ed) Essays in legal philosophy (1968) 61 62.

3 As above.

4 See para 17 which provides that 'social insurance should afford protection, in the contingencies to which they are exposed, to all employed and self-employed persons, together with their dependants'. 
Declaration of Human Rights, 1948 (Universal Declaration); ${ }^{5}$ the International Covenant on Economic, Social and Cultural Rights (ICESCR); ${ }^{6}$ the Convention on the Elimination of All Forms of Discrimination Against Women (CEDAW) ${ }^{7}$ and the Convention on the Rights of the Child (CRC). ${ }^{8}$

At the regional level, particularly in Africa, there is the African Charter on Human and Peoples' Rights (African Charter). ${ }^{9}$ While not directly providing for the right to social security or to an adequate standard of living as contained in the ICESCR, the African Charter contains specific provisions that have a bearing on social security. ${ }^{10} \mathrm{~A}$ number of policy activities, statements and recommendations have also been developed to enhance the right to social security in the region. ${ }^{11}$ These include the Principles and Guidelines on the Implementation of Economic, Social and Cultural Rights in the African Charter on Human and Peoples' Rights; ${ }^{12}$ the African Common Position on Human and Social Development in Africa 1994.13 the Ouagadougou Declaration and Plan of Action on Employment Promotion and Poverty Alleviation $2004 ;^{14}$ the Social Policy Framework for Africa $2008 ;^{15}$ the Yaounde Tripartite Declaration on

5 See arts 22, 23 and 25. It is worth noting that the provisions of the Universal Declaration are not legally binding on states except to the extent that some of the rights have attained the status of customary international law. See D Olowu 'The right to social security in Nigeria: Taking up the gauntlet' (2007) 1 Review of Nigerian Law and Practice 97.

6 See art 9(1).

7 See arts 11(1)(e) and 14(2)(c).

8 See art 26.

9 Adopted in 1981 by African Heads of State and Government, and eventually entered into force on 21 October 1986.

10 See eg art 18 on the right of the aged and the disabled to special measures of protection in keeping with their physical or moral needs, and art 16, which guarantees to every individual the right to enjoy the best attainable state of physical and mental health and the obligation imposed upon state parties to take the necessary measures to protect the health of their people and to ensure that they achieve medical attention when they are sick.

11 In the other regions, there is the European Social Charter 1961, aimed at granting to Europeans certain minimum standards concerning housing, health, education, employment, social protection, free movement and non-discrimination. See Part II of the European Social Charter. The Charter was revised in 1996 and the Additional Protocol providing for a system of collective complaints was adopted. There is also the European Code of Social Security, 1964 as well as the San Salvador Protocol to the American Convention on Human Rights in the area of Economic, Social and Cultural Rights, 1988. Furthermore, in 2009, the European Union adopted the Charter of Fundamental Rights of the European Union aimed at expanding the frontiers of protection of social rights in Europe.

12 http://www.achpr.org/files/instruments/economic-social-cultural/achpr_instr_gui de_draft_esc_rights_eng.pdf (accessed 5 September 2017).

13 A/CONF.166/PC/10/Add.1 http://www.un.org/en/africa/osaa/pdf/au/cap_social dev_1994.pdf (accessed 5 September 2017)

14 EXT.ASSEMBLY/AU/4(III)Rev $4 \mathrm{http} / /$ www.ilo.org/wcmsp5/groups/public/---africa /---ro-addis_ababa/documents/meetingdocument/wcms_234814.pdf (accessed 5 September 2017).

15 CAMSD/EXP/4(1) http://www.un.org/esa/socdev/egms/docs/2009/Ghana/au2. pdf (accessed 5 September 2017). 
the Implementation of the Social Protection Floors 2010; ${ }^{16}$ the Intergovernmental Regional Conference of the African Union on Social Protection 2006 (Livingstone Call for Action 2006); ${ }^{17}$ and the Report of the Follow-up on the Ouagadougou 2004 Extraordinary Summit of the African Union on Employment, Poverty Eradication and Inclusive Development in Africa $2014 .{ }^{18}$ At the micro level, the right to social security has been entrenched in the constitutions of several nations, either directly as an explicit justiciable right in the Bill of Rights, ${ }^{19}$ or indirectly as part of the Directive Principles of State Policy. ${ }^{20}$

In Nigeria, the right to social security remains illusory to a large majority of the citizenry as social security laws are targeted mostly at workers in the formal sector of the economy. Thus, poverty in the country has continued to worsen due to socio-economic challenges.

The aim of the article is to examine the range and scope of the right to social security in Nigeria within the context of the Nigerian Constitution and ancillary legislation. The scope of the enquiry includes relevant auxiliary programmes concerning social security. Attention is paid to areas of possible reform.

The article consists of six parts. The next and the third sections consider the justiciability of the constitutional provision on social security as well as other legislation with a special focus on the key policy areas of social security, namely, coverage, financing and benefit structure. The fourth section focuses on the extent of Nigeria's compliance with international instruments on social security, while section five is devoted to a discussion of both national and state governments' initiatives to alleviate poverty. The sixth and final section charts a way forward to improve the level of implementation of social security in Nigeria. I suggest the institutionalisation of taxfinanced, non-contributory schemes to address the needs of the informal sector of the economy. In furtherance thereof, it is necessary to first examine the legal foundation for social security in the country.

16 http://www.socialsecurityextension.org/gimi/gess/ RessourcePDF.do?ressource.ressourceld=25521 (accessed 5 September 2017).

17 http://www.ipc-undp.org/doc_africa_brazil/Livingstone-call-for-action.pdf (accessed 5 September 2017).

18 Assembly/AU/20 (XXIV) https://au.int/web/sites/default/files/newsevents/working documents/32162-wd-assembly_au_20_xxiv_e.pdf (accessed 5 September 2017).

19 See eg art 20(1) of the Basic Law of Germany; sec 27 of the Constitution of the Republic of South Africa, 1996; art 17 of the Constitution of Egypt 2014; art 43(1) of the Constitution of São Tomé and Principe, 1975; art 43 of the Constitution of the People's Republic of Bulgaria, 1971; art 165 of the Constitution of the Federal Republic of Brazil, 1982; art 50 of the Constitution of the People's Republic of China, 1978; and art 19 of the Constitution of the Republic of Columbia 1886 (as amended in 1981). In these countries, social security is no longer regarded as a policy option but as an enforceable fundamental right.

20 See eg the Constitution of the Federal Republic of Nigeria 1999 (as amended) and the 1991 Constitution of Sierra Leone. 


\section{Legal basis for social security in Nigeria}

The right to social security is given recognition in section $14(2)$ (b) of the Constitution of the Federal Republic of Nigeria, 1999, ${ }^{21}$ which provides that 'the security and welfare of the people shall be the primary purpose of government'.22

This section is included in Chapter II of the Constitution entitled 'Fundamental Objectives and Directive Principles of State Policy'. ${ }^{23}$ Chapter II of the 1999 Constitution also contains provisions on the right to suitable and adequate shelter; suitable and adequate food; a reasonable national minimum living wage; old age care and pensions; unemployment benefits; sick benefits and welfare of the disabled; ${ }^{24}$ the right to adequate medical and health facilities; ${ }^{25}$ and the right to education. ${ }^{26}$ These provisions are key components of a viable social security scheme. However, they are prima facie non-justiciable by virtue of the provisions of section 6(6)(c) of the Constitution which has generally ousted the jurisdiction of the court in respect of

any issue or question as to whether any act or omission by any authority or person or as to whether any law or any judicial decision is in conformity with the Fundamental Objectives and Directive Principles of State Policy set out in Chapter II of this Constitution. ${ }^{27}$

\section{As amended.}

22 My emphasis.

23 Generally, Directive Principles are fundamental in the governance of a country. They have been likened to the instruments of instructions which were issued to the Governor-General and the Governors of Colonies and to those of India by the British government under the 1935 Government of India Act. The only difference is that they are instructions to the legislature and the executive. Whoever captures power will not be free to do what he likes with it. In the exercise of it, he will have to respect these instruments of instructions, which are called Directive Principles. See DD Basu Commentary on the Constitution of India (1965) 311-312. A similar view has been expressed by a Nigerian legal luminary, Nwabueze, that, although the Directive Principles are not legally enforceable, they provide a yardstick for the critical assessment of government actions. See BO Nwabueze Constitutional law of the Nigerian Republic (1964) 408. Although the Nigerian Constitution 1963 did not contain provisions on directive principles, Nwabueze addressed and commented on directive principles as a concept when he published his work in 1964. Yet, the penetrating force of that commentary has shed some light on the debate about the viability of the same concept when, eventually, it manifested in the 1979 Nigerian Constitution and, subsequently, in that of 1999, in such a way that we have seen it as a credible authority to sustain our discourse. It has not been cited as authority for the 1979 or 1999 Constitutions per se, which it predated.

24 Sec 16(2)(d) 1999 Constitution.

25 Sec 17(2)(d) 1999 Constitution.

26 Sec 18(1) 1999 Constitution.

27 In Badejo v Federal Minister of Education (1990) LRC (Const) 735, the Court of Appeal affirmed the decision of the trial court which declined to assume jurisdiction in an action challenging the government's university admission policy on the ground that the action sought to establish a right to education, and held that education was not a right but a Directive Principle, unenforceable under the Constitution. See also Archbishop Anthony Olubunmi Okogie \& Others $v$ AttorneyGeneral of Lagos State (1981) 2 NCLR 337; Uzuokwu v Ezeonu II (1991) 6 NWLR (Pt 200) 708. 
In essence, therefore, the rights enunciated in Chapter II of the Constitution are not binding legal entitlements, but mere aspirational goals. The non-justiciability of these rights is said to have been informed largely by fiscal constraints. ${ }^{28}$

Nevertheless, the Fundamental Objectives and Directive Principles of State Policy are not without juridical value in the sense that the qualification precluding judicial review of the provisions of Chapter 11 of the Constitution, itself, is subject to the other provisions thereof. ${ }^{29}$ Also, under the Exclusive Legislative List on which the National Assembly has power, by virtue of section 4 of the Constitution, 'to make laws for the peace, order and good government of the Federation or any part thereof', the National Assembly is empowered to establish and regulate authorities for the Federation or any part thereof 'to promote and enforce the observance of the Fundamental Objectives and Directive Principles contained in this Constitution' ${ }^{30}$ Therefore, while individuals may not have the locus standi to bring an action to court for the infringement of any of the provisions of the Directive Principles of State Policy of which social security forms a part, these are clear constitutional provisions of which the National Assembly may take advantage, through legislative fiat, to ensure that government and its agencies carry out their obligations in respect thereof.

Furthermore, in Attorney-General of Ondo State $v$ Attorney-General of the Federation \& Others, ${ }^{31}$ the Supreme Court reiterated the fact that, while the Fundamental Objectives and Directive Principles of State Policy remain mere declarations and cannot be enforced by legal procedure, it would be seen as a failure of duty and responsibility of state organs if they acted in clear disregard of them. According to the Court, the nature of the consequences of such failure depends on the aspect of the infringement and, in some cases, the political will of those in power to redress the situation. It was further held that the

28 See eg Nwabueze (n 23 above) where he argues that it would be inappropriate to compel the government by way of a judicial fiat to allocate resources which it does not have towards the actualisation of socio-economic rights. Other challenges to the implementation of these rights have been identified as locus standi, justiciability and dualism. See S Ibe 'Implementing economic, social and cultural rights in Nigeria: Challenges and opportunities' (2010) 10 African Human Rights Law Journal 203.

29 In Federal Republic of Nigeria $v$ Anache \& Others (2004) 14 WRN 1 61, Justice Niki Tobi stated that the non-justiciability of $\sec 6(6)(c)$ of the Constitution is neither total nor sacrosanct as the subsection provides leeway by the use of the phrase 'except as otherwise provided by this Constitution'. According to the judge, if the Constitution otherwise provides in another section, which makes a section or sections of $\mathrm{Ch}$ II justiciable, it will be so interpreted by the courts.

30 See para 60(a) of Part I of the Second Schedule to the 1999 Constitution. See also sec 13 of the Constitution which imposes a duty on all organs of government and all authorities and persons exercising legislative, executive or judicial powers to conform to, observe and apply the provisions of Ch II and sec 224, which requires the programme, aims and objects of a political party to conform with the provisions of $\mathrm{Ch}$ II of the Constitution. 
Directive Principles (or some of them) could be made justiciable by legislation and that the purpose of including these Directive Principles of State Policy within the Exclusive Legislative List under item 60(a) was to show that they can be turned into enactments by the National Assembly should the need arise. ${ }^{32}$ According to the Supreme Court, section 16(2)(d), for instance, could be legislated upon to ensure that suitable and adequate shelter, suitable and adequate food, reasonable national minimum living wages, old age care pensions, unemployment and sick benefits and welfare of the disabled are provided for all citizens.

At a comparative level, the right to social security in the Constitution of the Republic of South Africa, 1996 is directly enforceable in cases of violations. According to section 27(1)(c) of the 1996 Constitution, everyone has the right to have access to social security including - if they are unable to support themselves and their dependants - appropriate social assistance. Under section 27(2) thereof, the state is obliged to take reasonable legislative and other measures, within its available resources, to achieve the progressive realisation of the right of access to social security. 'Other measures', in this context, has been interpreted to mean 'financial, administrative, judicial, economic, social and educational measures'.$^{\prime 3} 3$ In this regard, in Ex parte Chairperson of the Constitutional Assembly: In re Certification of the Constitution of the Republic of South Africa, ${ }^{34}$ the Constitutional Court has noted that the socio-economic rights contained in the Constitution are justiciable even though the inclusion of the rights may have direct implications for budgetary matters.

It has been noted that the significance of this decision is that the Court has declared a 'floor' of minimum justiciability and will not permit government interference with access to the social rights in question, nor discrimination in the provisioning of such rights. ${ }^{35}$ Thus, in Khosa \& Others $v$ Minister of Social Development, ${ }^{36}$ a law that excluded permanent residents and their children from access to social assistance was successfully challenged and found to be unreasonable and inconsistent with the provisions of section 27(1), which

32 The Fundamental Objectives and Directive Principles of State Policy contained in Ch 11 of both the 1979 and 1999 Constitutions have lain dormant since 1979. The Corrupt Practices and Other Related Offences Act, 2000, Cap C 31, LFN, 2004 was the first effort to activate just one aspect of them - sec 15(5) - in order that there may be good and transparent government throughout Nigeria.

33 See Child Health Policy Institute and the South African Federal Council on Disability Social security policy options for people with disabilities in South Africa: An international and comparative review http://www.ci.org.za/depts/ci/pubs/pdf/ poverty/resrep/polopt4ds.pdf. (accessed 19 April 2015).

341996 (4) SA 744 (CC) paras 76-78. See also Government of Republic of South Africa $\checkmark$ Irene Grootboom \& Others 2001 (1) SA 46 (CC).

35 See CE Christiansen 'Adjudicating non-justiciability rights: Socio-economic rights and the South African Constitutional Court' (2007) 38 Columbia Human Rights Law Review 321359.

362004 (6) SA 505 (CC). See also Grootboom (n 34 above); Minister of Health $v$ Treatment Action Campaign (No 2) 2002 (5) SA 721 (CC). 
guarantees to everyone the right of access to social security and social assistance, as well as with section 9(3), which prohibits unfair discrimination.

In similar vein, although the 1992 Ghanaian Constitution does not have an explicit provision on social security similar to the South African Constitution, the few provisions thereon, including article 28, which gives protection to the rights of children, and article 29, which protects the rights of disabled persons, are contained in the Bill of Rights and not as policies or principles as is the case of Nigeria. Therefore, the justiciability of these rights in Ghana is certain. However, the right to health, as in Nigeria, is recognised as one of the Directive Principles of State Policy. Unlike Nigeria, however, article 33(5) of the 1992 Ghanaian Constitution further makes provision for other socio-economic rights, which are not expressly contained in the Bill of Rights, to be included therein in appropriate circumstances. Furthermore, there are safeguard provisions in the Ghanaian Constitution to ensure that the provisions on the Directive Principles are duly implemented. ${ }^{37}$ It is worth noting that the judicial power to enforce socio-economic rights is not confined to those listed under the Bill of Rights, but extends to those laid out in the Directive Principles of State Policy. In New Patriotic Party $v$ Attorney-General, ${ }^{38}$ it was held that, although the Directive Principles of State Policy are not in themselves legally enforceable by the courts, there are exceptions to this principle in that, where the Directive Principles are read together with other enforceable parts of the Constitution, they may become enforceable.

In India, the relevant constitutional provisions on social security as well as other socio-economic rights, as is the case in Nigeria, are contained under the Directive Principles of State Policy and are also declared to be non-enforceable. ${ }^{39}$ Nevertheless, through judicial activism, ${ }^{40}$ the Indian Supreme Court, over the years, has held that these principles are essential in interpreting the content of fundamental rights. Accordingly, it has gradually widened the definition of rights held to be constitutionally justiciable, such as the right to life guaranteed in article 21 of the Constitution, to include the right to a livelihood and the basic necessities of life. ${ }^{41}$ Also, it has applied a more substantive conception of equality to uphold socio-

\footnotetext{
37 See eg arts 34(1) \& (2) of the Ghanaian Constitution.

38 (1996-97) SCGLR 729788.

39 Indeed, there is a general belief that the concept of Fundamental Objectives and Directive Principles of State Policy was borrowed from India. The relevant provisions are similar to those of Part IV of the Indian Constitution 1950.

40 Judicial activism, it has been said, can mean many things, ranging from scrutiny of legislation to determine constitutionality, the creation of law to the exercise of policy prerogatives normally reserved for the executives. See PB Mehta 'India's unlikely democracy: The rise of judicial sovereignty' (2007) 18 Journal of Democracy 7079.
}

41 See Rathinam v United Sharma (1994) 3 SC 394. In Francis Coralie Mullin $v$ The Administrator, Union Territory of Delhi (1981) 2 SCR 516, the Supreme Court held 
economic rights, such as the right to health, education and shelter. ${ }^{42}$ The rationale behind the pro-active stance of the Indian judiciary to directive principles may be gleaned from the powerful dissenting judgment of Justice Bhagwati in Minerva Mills Ltd $v$ Union of India, where he stated: 43

There are millions of people in the country who are steeped in poverty and destitution and for them, these civil and political rights have no meaning. It was realised that to a large majority of people who are living in almost subhuman existence, in conditions of abject poverty and for whom life is one long broken story of want and destitution, notions of individual freedom and liberty, though representing some of the most cherished values of a free society would sound as empty words bandied about only in the drawing rooms of the rich and well-to-do and the only solution for making these rights meaningful to them was to remake the material conditions and usher in a new social order where socio-economic justice will inform all institutions of public life so that the preconditions of fundamental liberties for all may be secured.

In the context of the present discussion, some fundamental clarification regarding the integrity of the relevant legal order governing social security in Nigeria is provided next.

\section{Some concerns about the current Nigerian laws on social security}

The Social Security (Minimum Standards) Convention 1952 of the ILO provides for minimum standards in nine distinct branches of social security, namely, medical care; sickness; unemployment; old-age; employment injury; family; maternity; invalidity; and survivorship. ${ }^{44}$ The Convention also introduces the idea of a general level of social security that should be attained progressively everywhere since the system can be adapted to the economic and social conditions prevailing in each country, whatever the degree of its development. A state is required to, at least, accept three of these branches and, at least, one of which must be of a long-term nature (that is, old age, invalidity, unemployment, employment injury or survivors' benefits) to ratify the Convention and before it can be given recognition as a state providing social security to its citizenry. 45

that the right to life guaranteed under art 21 of the Indian Constitution included the right to live with human dignity and all that goes with it.

42 See eg Tellis \& Another $v$ Bombay Municipal Corporation \& Others (1987) LRC (Const) 351; Shantistar Builders v Narayan Khimalal Totame \& Others (1990) 1 SCC 520; Consumer Education and Research Centre (CERC) v Union of India (1995) 3 SCC 42; Ahmedabad Municipal Corporation v Nawab Khan Gulab Khan \& Others (1997) AIR SC 152; Paschim Banga Khet Mazdoor Samity $v$ State of West Bengal (1996) AIR SC 2426; Jain v State of Kamataka (1992) 3 SCC 666; Krishnan v State of Andhra Pradesh \& Another (1993) 4 LRC 234.

43 (1980) AIR SC 179186.

44 See Parts II, III, IV, V, VI, VII, VIII, IX and $\mathrm{X}$ respectively of the Social Security (Minimum Standards) Convention 1952 (No 102).

45 See art 2 of the Social Security (Minimum Standards) Convention 102 of 1952. 
The laws regulating social security in Nigeria include the Pension Reform Act (PRA) of 2014, which regulates, inter alia, the provision of retirement benefits as and when due to every person who worked in the formal employment of either the public service of the Federation, the federal capital territory, states, local governments or the organised private sector, ${ }^{46}$ as well as the payment of disability benefits in appropriate cases and survivors' benefits to dependant(s) of a deceased employee. ${ }^{47}$ The National Health Insurance Scheme (NHIS) Act of $1999^{48}$ establishes a contributory health insurance scheme to which every employer who has a minimum of ten employees, together with every person in his employment, pay contributions, which entitles insured persons and their dependants to the benefits of prescribed good-quality and cost-effective health services. The Employees' Compensation Act of 2010 regulates the provision of an open and fair system of guaranteed and adequate compensation for all employees or their dependants for any death, injury, disease or disability arising out of or in the course of employment. ${ }^{49}$ It is worth noting that, although all the prescribed branches of social security are included in the Directive Principles of State Policy, only five of those branches, namely, old age, disability, survivors, medical and work injury benefits, have been directly legislated, while there is limited provision for sickness and maternity benefits under the Labour Act of 1974. ${ }^{50}$ As yet there is no provision for unemployment, nonoccupational disability and family benefits in Nigerian law. It should be noted that, in countries like South Africa, the Social Assistance Act of 2004, in sections 6 and 9, makes provision for the payment of means-tested tax-financed child support and disability grants respectively to citizens and residents who satisfy the prescribed qualifying conditions, while the Unemployment Insurance Act of 2001 makes provision for a contributory scheme that pays out sickness and maternity as well as unemployment benefits to contributors. ${ }^{51}$

Moreover, although Nigeria could be regarded as a country which provides social security for her citizens, the various afore-mentioned Nigerian laws are too limited in their coverage as they all are essentially employment-related. Thus, contrary to the provisions of paragraph 29 of the Income Security Recommendation 67 of 1944

46 See secs 1, 3, 7, 8, 9 \& 10 of the Pension Reform Act 2014.

47 See secs $16 \& 8$ respectively of the Pension Reform Act 2014.

48 See sec 1 of the National Health Insurance Scheme Act 1999.

49 The Nigeria Social Insurance Trust Fund Act 73 of 1993 is another legislation which hitherto has regulated the payment of retirement, disability and survivors' benefits for contributors to the Fund who work in the private sector of the economy. Although the Act has not been repealed, the benefit structure of the Fund has been harmonised with that of the public sector under the defined contribution scheme of the Pension Reform Act 2004, which has been re-enacted as the Pension Reform Act 2014.

50 Secs $16 \& 54$ respectively of the Labour Act 1974.

51 See secs 20, 24 \& 16 respectively of the Unemployment Insurance Act 2001 (as amended). 
that 'invalids, aged persons and widows who are not receiving social insurance benefits because they or their husbands, as the case may be, were not compulsorily insured, and whose income does not exceed a prescribed level', should be provided with a special maintenance allowance at prescribed rates, the vast majority of the Nigerian population, such as the aged, the disabled, the orphaned and the self employed who, more often than not, do not have any form of assistance from any quarters, are left without any form of a social safety net. ${ }^{52}$ The best that these laws have offered those not ordinarily covered by them is to join the various schemes as voluntary members. ${ }^{53}$ Indeed, among the positions covered in the organised private sector, these laws exclude positions where the number of employees is fewer than a particular number. For example, the Pension Reform Act in section 2(2) limits private sector participation to employees who are in the employment of an organisation in which there are 15 or more employees. Similarly, section 16 of the NHIS Act restricts coverage to positions in which the employer has a minimum of ten employees, and enrolment is even at the discretion of the employer. It is only under the Employees' Compensation Act that coverage has been extended to all employers and employees in the public and private sectors in Nigeria, including apprentices, casual workers and domestic servants who are not members of the families of their employers. ${ }^{54}$ Notwithstanding, coverage under the law is not wide enough when compared to the laws of some other African countries like Algeria, Benin, Cameroon, Côte d'Ivoire, Tunisia and Senegal, where coverage for work injury compensation practically extends to all employees including the self-employed, students in technical schools, prisoners and wards of juvenile courts. ${ }^{55}$ The selfemployed, whether in the agricultural or manufacturing sector, are in the majority in Nigeria and are exposed daily to accidents on duty.

It is also worth noting that the formal sector covered by the available schemes represents only about 20 to 25 per cent of the Nigerian population. Thus, general coverage for social security in Nigeria is not in compliance with the classes of employees prescribed, constituting not less than 50 per cent of all employees, and also their wives and children. ${ }^{56}$ While acknowledging the fact that many developing countries, especially in Africa, limit coverage for social

52 Para 17 of the Income Security Recommendation also provides that social insurance should afford protection, in the contingencies to which they are exposed, to all employed and self-employed persons, together with their dependants, in respect of whom it is practicable.

53 Sec 17(3) NHIS Act; sec 2(3) Pension Reform Act 2014 and Regulation 13 of the NSITF (General) Regulations) 1994 (Nigeria).

54 Secs 2(1) \& 73 of the Act.

55 Social Security Administration and International Social Security Association Social security programmes throughout the World: Africa, 2015 (2015) file://C:/Users/MRS \%20ANIFALAJE/Downloads/MagazineSSPT8.pdf (accessed 5 September 2017).

56 See eg arts 9, 15 \& 27 of the Social Security (Minimum Standards) Convention 102 of 1952 in respect of medical care, sickness and old age benefits respectively. 
security protection to only employees in the formal sector of the economy, it is remarkable that others, such as South Africa, Swaziland, Botswana, Mauritius, Namibia, Seychelles, Lesotho and Cape Verde, do have institutionalised schemes to provide protection to all their citizens, at least, for the contingency of old age, while some also have extended most of the other social security schemes to the selfemployed. ${ }^{57}$ Limiting social security coverage to those in the formal sector of the economy is clearly a vestige of colonialism which must be jettisoned by an independent Nigerian state. However, it is worth noting that a Bill which seeks to improve on the existing coverage of the NHIS is currently being considered by the National Assembly. The Bill, if passed into law, would repeal the NHIS Act and enact the National Health Insurance Commission Act. One of the reforms envisaged by the Bill is to make enrolment in the health insurance scheme mandatory for employers who have, at least, five employees in their employ. ${ }^{58}$

Another area of concern about the Nigerian laws on social security is the financing of the available schemes. The guiding principle on the share of the cost of benefits to be borne by the state, the employer and the employee is laid down in ILO Income Security Recommendation 67 of 1944 which stipulates that the cost of benefits, including the cost of administration, should be distributed among insured persons, employers and taxpayers, in such a way as to be equitable to insured persons and to avoid hardship to insured persons of small means or any disturbance to production.59 Specifically, it requires that employers should be made to bear the entire cost of compensation for employment injury, that they should contribute not less than half the total cost of the other benefits and that the community should bear the cost of benefits which cannot be met by contributions, for example, contribution deficits resulting from bringing persons into insurance when they are already elderly; contingent liability involved in guaranteeing the payment of basic invalidity, old-age and survivors' benefits and the payment of adequate maternity benefit; liability resulting from the extended payment of unemployment benefits when unemployment persists at a high level; and subsidies to the insurance of self-employed persons of small means. ${ }^{60}$ Similarly, article 71(1) of the Social Security (Minimum Standards) Convention of 1952 requires that the cost of benefits, including the cost of administration, should 'be borne collectively by way of insurance contributions or taxation or both in a manner which avoids hardship to persons of small means and takes into account the

57 See sec 10 of the Social Assistance Act 13 of 2004 (South Africa); Social Security Administration and International Social Security Association (n 55 above).

$58 \mathrm{~N}$ Popoola 'FG set to make health insurance compulsory for employers' (2017) http://punchng.com/fg-set-to-make-health-insurance-compulsory-for-employers/ (accessed 5 September 2017).

59 See para 26 of the Income Security Recommendation 67 of 1944.

60 As above. 
economic situation of the member and of the classes of persons protected'. Also, ILO Medical Care Recommendation 69 of 1944 stipulates that medical care may be provided by a social insurance medical care service or a public medical care service.

However, a distinction is drawn between the two services in terms of the way in which they are financed. On the one hand, as regards the social insurance medical care service, which normally is financed by means of contributions, the instrument stipulates that persons whose income does not exceed subsistence level should not be required to pay an insurance contribution and that the cost of the medical care service not covered by contributions should be borne by the tax payers. On the other hand, the cost of the public medical care service is required to be met out of public funds. Where the whole population is covered, it is recommended that the service be financed out of general revenue or by a special progressively-graded tax from which persons whose income does not exceed subsistence level should be exempted.

In Nigeria, with the exception of compensation for work injury under the Employees' Compensation Act which, traditionally, is financed exclusively by employers, ${ }^{61}$ all available social security schemes are financed by means of contributions by employers and employees without any form of financial assistance from the government, contrary to the foregoing stipulated guidelines. For instance, section 4 of the Pension Reform Act makes prescribed contributions, payable by employees and employers, the major source of funding of the Retirement Savings Account (RSA) of each employee. ${ }^{62}$ Also, the NHIS Act, in section 16 , requires the payment of contributions by employers and employees, at such a rate and in such a manner as may be determined from time to time by the scheme's governing council. The sickness and maternity benefits that are available under the Labour Act are based on employer-liability schemes as opposed to social insurance schemes that are generally prescribed by international standards. ${ }^{63}$ There is no government subsidy to any of these schemes, not even by way of subvention, to cover administration costs. Regrettably, whatever financial commitment the government has in respect of these schemes has been in its capacity as employer of specified employees, just as any other employer. It is also worth noting that Nigeria is yet to ratify the Social Security (Minimum Standards) Convention of 1952 or any of the ILO Conventions on social security. The government's perception of and response to unambiguous international instruments on social security in Nigeria are addressed below.

61 See para 26(5) of the Income Security Recommendation 1944 which provides that the entire cost of compensation for employment injuries should be contributed by employers.

62 Sec 4(3) of the PRA 2014, however, permits an employee to make voluntary contributions into his Retirement Savings Account if he or she so desires.

63 See eg art 8 of the Maternity Protection Convention 183 of 2000. 


\section{Nigeria's compliance with international legal instruments on social security}

Nigeria is a state party to a number of international instruments which require state parties to protect and promote the right to social security. For example, on 29 July 1993 Nigeria ratified the ICESCR, which in article $9(1)$ requires state parties to assume a legal obligation to recognise 'the right of everyone to social security, including social insurance'. State parties are generally required to provide some form of social insurance scheme to protect people against the risks of sickness, disability, maternity, employment injury, unemployment or old age, to provide for survivors, orphans and those who cannot afford health care and to ensure that families are adequately supported. Benefits from such a scheme must be adequate, accessible to all and provided without discrimination. ${ }^{64}$

Also, with respect to medical benefits, Nigeria is a state party to a number of international and regional instruments wherein the right to health is recognised. ${ }^{65}$ According to article $12(1)$ of the ICESCR, for example, state parties to the Covenant 'recognise the right of everyone to the enjoyment of the highest attainable standard of physical and mental health'. Of particular note also is the African Charter, which Nigeria has not only ratified, but domesticated in the African Charter on Human and Peoples' Rights (Ratification and Enforcement) Act. ${ }^{66}$ Article 16 of the Charter provides:

(1) Every individual shall have the right to enjoy the best attainable state of physical and mental health.

(2) State parties to the present Charter shall take the necessary measures to protect the health of their people and to ensure that they receive medical attention when they are sick.

In essence, medical benefits, in the context of the ILO's Social Security (Minimum Standards) Convention of 1952, ought to be provided to all. It is admitted, however, that the ICESCR has not conceptually defined what is meant by 'the highest attainable standard of physical and mental health, including the specific measures expected to be adopted by state parties to protect the health of their citizens, nor has the African Charter 'the best attainable state of physical and mental health' with any particular certainty. This, arguably, may constitute some hindrance to the enforcement of the right as enshrined in both instruments. Nevertheless, having ratified the ICESCR, Nigeria is to be guided by General Comment 14 of the Committee on Economic,

64 See ESCR Committee General Comment 9 'The right to social security' 4 February 2008 http://www.ohchr.org/english/bodies/cescr/discussion.htm (accessed 18 February 2015).

65 See eg art 25(1) Universal Declaration; arts 11(1)(f) and 12 CEDAW; art 24 CRC.

66 Cap A 9, LFN 2004, art 16. 
Social and Cultural Rights (ESCR Committee) ${ }^{67}$ which has given some clarification and operational guidelines to the provisions of article 12 of the Covenant. According to the Committee, the right to health encompasses not only the usual health care, but also a wide range of socio-economic factors that promote conditions in which people can lead a healthy life. This extends not only to timely and appropriate health care, but also to the underlying determinants of health, such as food and nutrition, housing, access to safe and potable water, and adequate sanitation, safe and healthy occupational and environmental conditions and access to health-related education and information, including sexual and reproductive health. ${ }^{68}$ It is submitted, therefore, that although the African Charter is not superior to the Nigerian Constitution, 69 the constitutional provision concerning nonjusticiability of the right to medical benefits in Nigeria could be overcome by taking into consideration the provisions of article 12 of the ICESCR and the interpretation guideline contained in General Comment 14 and other socio-economic rights in general, and through purposive judicial interpretation of the provisions of article 16 of the African Charter (Ratification and Enforcement) Act in particular.

Indeed, in Abacha $v$ Fawehinmi, ${ }^{70}$ the Supreme Court referred to its earlier decision in Ogagu $v$ State, $^{71}$ and held that since the African Charter had become part of domestic law, the enforcement of its provisions, like all our other laws, falls within the judicial powers of the courts as provided for by the Constitution and laws relating thereto. It was held that the rights enumerated in the African Charter are enforceable by the several High Courts depending on the circumstances of each case and in accordance with the rules, practice and procedure of each court. ${ }^{72}$ It is to be noted that, apparently, due to some pangs of conscience, successive Nigerian governments have

67 See ESCR Committee General Comment 14 'The right to the highest attainable standards of health' 11 August 2000 UN Doc E/C.12/2000/4, http://www. unhchr.ch/tbs/doc.nsf/(symbol)/E.C.12.2000.4.En (accessed 15 December 2014).

68 General Comment 14 (n 67 above) paras $4 \& 11$.

69 See, however, Abacha \& Others v Fawehinmi (2000) 6 NWLR (Pt 660) 228, where the Supreme Court held that the African Charter was a special genus of law in the Nigerian legal and political system and that it had some international flavour and, in that sense, cannot be amended, watered down or sidetracked by any Nigerian law. It was further held that if there is a conflict between the African Charter and another statute, its provisions will prevail over those of that other statute for the reason that the legislature does not intend to breach an international obligation.

70 As above; see also Ohakosim v COP (2009) 15 NWLR (Pt 1164) 229 CA, where the Court of Appeal held that by virtue of the African Charter on Human and Peoples' Rights (Ratification and Enforcement) Act, Cap A9, LFN 2004, the Charter constitutes part of the laws of Nigeria and must be upheld by all courts in the country. The Court further held that Nigeria had given due recognition to the Charter by enshrining most of the rights and obligations guaranteed therein in $\mathrm{Ch}$ IV of the 1999 Constitution; see also sec 1 of the Act.

71 (1994) 9 NWLR (Pt 366) 1 SC.

72 See eg Jonah Gbemre \& Others $v$ Shell Petroleum Development Company of Nigeria Ltd \& Others FHC/CS/B/153/2005, Federal High Court, Benin City, judgment of 14 November 2005 (unreported), where it was held that the right to life and dignity of the person as recognised in secs 33(1) and 34(1) of the 1999 
taken a number of social welfare steps which are explicated upon below.

\section{Social security as poverty alleviation and social protection programmes}

Ideally, social security is a permanent social welfare structure which aims at a piecemeal and steady incremental improvement in the quality and standard of living of the citizenry. There is no gainsaying the fact that, in most developing communities such as Nigeria, there is a causal relationship between the absence of social security on the one hand, and poverty, on the other. However, the government initiatives which focus on temporary or permanent poverty eradication, are not social security measures, but are transient steps taken to form a suitable foundation on which social security programmes may be based. For example, in 2004 a survey of policies and interventions of various administrations on issues of poverty revealed 28 federal projects and programmes with poverty-reduction aims. ${ }^{73}$ These include community banks; the Family Support Programme; the National Directorate of Employment; the Peoples' Bank; Better Life for Rural Women; and the Directorate of Food, Road and Rural Infrastructure. These are some of the programmes that were established to address various manifestations of poverty, such as unemployment, lack of access to credit and rural and gender dimensions of poverty.

Also, since 1999 the federal government has undertaken a series of initiatives aimed at addressing poverty and other socio-economic challenges confronting the country's population. These include the National Economic Empowerment and Development Strategy (NEEDS), replicated in the various states and local governments as the State Economic Empowerment and Development Strategy and Local Economic Empowerment and Development Strategy respectively; and the National Poverty Eradication Programme (NAPEP).The principal goals of NEEDS include reorienting values, reducing poverty, creating wealth, and generating employment. ${ }^{74}$ The NAPEP focuses attention on co-ordinating all the poverty eradication programmes or activities of other arms of government, as well as people's economic empowerment, especially vulnerable groups, such as women and the young unemployed graduates of universities or other vocational

Constitution and arts 4, 16 and 24 on the right to life, health care and satisfactory environment respectively of the African Charter Act inevitably include the right to clean, poison-free, pollution-free and healthy environment, thereby invariably upholding the right to a healthy environment contained in section 20 of the 1999 Constitution, which is a Directive Principle.

73 National Planning Commission National economic empowerment and development strategy (2004) 33.

74 National Planning Commission (n 73 above) IX. 
institutions. ${ }^{75}$ In 2002 alone, the Poverty Eradication Fund ${ }^{76}$ allocated to the core poverty-eradication ministries and agencies a total of $\mathrm{N}$ 13247 billion ( $\$ 1,10$ billion). ${ }^{77}$

Also, in 2008, the Yar'Adua-led administration distributed the sum of $A 1$ billion (\$8,47 million) ${ }^{78}$ to a total of 12000 poor households for investment in micro-businesses under a presidential pet project known as In Care of the People (COPE) Programme, Poverty Reduction Accelerator Investment (PRAI). The project was implemented by NAPEP, in conjunction with the former office of the Millennium Development Goals and the Small and Medium Enterprises Development Agency. ${ }^{79}$ The project was said to be Nigeria's own Conditional Cash Transfer (CCT) initiative aimed at reducing vulnerabilities and intergenerational poverty amongst extremely poor households. ${ }^{80}$ However, one could hardly find any equity in or justification for distributing $\mathrm{N} 1$ billion ( $\$ 8,47$ million) to only 12000 poor households out of the then estimated 70 million

75 See M Oloja \& M Onuorah 'NAPEP is creating a new class of self-employed' The Guardian 19 June 200527.

76 See Central Bank of Nigeria Central Bank of Nigeria Annual Report and Statement of Accounts 2002 Abuja: Central Bank of Nigeria 54.

77 The official average US dollar exchange rate to naira in 2002 was N $120 \mathrm{http}: / /$ www.indexmundi.com/facts/nigeria/official-exchange-rate (accessed 6 September 2017).

78 The official average US dollar exchange rate to naira in 2008 was N 180.

79 Editorial 'How not to alleviate poverty' The Guardian 11 January 200814

80 The Conditional Cash Transfer (CCT) programme provides regular cash benefits to all families, or to poor families in particular, and have been found to have a strong impact on various dimensions of human development whether they are explicitly linked to health and education-related conditions or not. The idea of the CCT programme was first introduced in Mexico with the establishment of the Progresa/ Oportunidades programme; ILO World Social Protection Report 2014/15. Building economic recovery, inclusive development and social justice www.llo.org/publns. 46 (accessed 21 December 2015). In Africa, the Livingstone Call for Action 2006, inter allia, called on African governments to utilise the option of developing national social protection frameworks and cash transfer programmes that would provide social pension and social transfers to vulnerable children, older persons and persons with disabilities and households. At present, a number of CCT programmes have been established in some African countries. These include Cameroon's Social Safety Net Project which targets close to 65000 rural and urban households in five regions of the country, including 5000 urban households in the cities of Douala and Yaounde. The project includes a cash transfer programme and it also co-ordinates income-generating activities for the poorest. See O Hegba 'A cash transfer programme improves the lives of Cameroon's poorest families' (2016) http://www.worldbank.org/en/news/feature/ 2016/03/03/a-cash-transfer-program-improves-the-lives-of-cameroons-poorestfamilies (accessed 5 September 2017); the Tanzania's cash transfer programme, a part of the country's Productive Social Safety Net Project which aims to increase food security among vulnerable groups, improve access to health and education services, and enhance and protect the human capital investment in children. See World Bank Group 'Tanzania's conditional cash transfer programme helps reduce extreme poverty' (2016) http://www.worldbank.org/en/news/feature/ 2016/11/18/tanzanias-conditional-cash-transfer-program-helps-reduce-extremepoverty (accessed 5 September 2017); the Ghanaian Livelihood Empowerment Against Poverty Programme (LEAP) currently implemented in about half of Ghana's districts; and Mozambique's Programa Subsidio de Alimentos cash transfer programme; ILO World Social Protection Report 2014/15. 
poor people. Such a programme was not a social security measure and could not be said to have achieved its primary objectives, as it was targeted at only a negligible few of the potentially-qualifying households.

The Jonathan-led administration also inaugurated a number of programmes, such as the Youth Enterprise With Innovation in Nigeria (YouWin), funded in part from the $\mathrm{N} 50$ billion ( $\$ 326$ million) ${ }^{81}$ Job Creation Fund, which was set aside in the 2011 budget. The YouWin was an innovative business plan targeted at owners of existing formal and informal businesses and geared towards harnessing the creative energies of young people between the ages of 18 and 35 years. The programme was expected to create between 80000 and 110000 sustainable jobs over a four-year period. ${ }^{82}$ Another programme was the Subsidy Reinvestment and Empowerment Programme (Sure-P) aimed at creating employment for the unemployed, particularly the youth, through public work schemes. One of the objectives of the Sure-P was to enhance the employability of at least 50000 unemployed graduates in the 36 states of the Federation by improving their skills through job placement. ${ }^{83}$ As of 2014, the YouWin programme was said to have had 3600 winners, among whom 2400 winners were said to have created 27000 jobs, while the SURE-P was said to have created 120000 jobs. $^{84}$

In the 2016-2018 Medium-Term Expenditure Framework and Fiscal Strategy Paper presented to the National Assembly, the Buhari-led administration proposed to spend $\mathrm{N} 500$ billion ( $\$ 1,63$ billion) ${ }^{85}$ on social services to cater for the needs of the youth and other vulnerable groups. In the proposal, which has been approved by the National Assembly, the Social Welfare Programme, which is planned to be executed in phases, is to take care of the school-feeding programme initiative where 5,5 million children are to be fed for 200 school days, and the Conditional Cash Transfer under which a $N 5000,00$ $(\$ 16,39)$ monthly stipend would be paid to one million beneficiaries considered to be the most vulnerable and poor, and a post-NYSC grant. $^{86}$

State governments, in conjunction with their respective local governments, have acted in tandem through a number of policy initiatives to bring government activities to bear at the sub-national

81 The official average US dollar exchange rate to naira in 2011 was $\mathrm{N} 153$.

82 O Adetayo \& J Onuba 'Jonathan unveils initiative to create 110000 jobs' The Punch 22 October 201119.

83 S Aborisade 'Unemployment: Sure-P boss decries firms' response to GIS' The Punch 21 August 201338.

84 See Anon '1.8 million graduates enter job market yearly - FG' The Punch 2 April 20142.

85 The official average US dollar exchange rate to naira in 2016 was $\mathbb{} 305$ https:// www.cbn.gov.ng/rates/exrate.asp?year=2016 (accessed 6 September 2017).

86 See J Ameh \& S Aborisade 'FG to spend N500 bn on poor Nigerians in 2016' The Punch 9 December 20153. 
level. The focus has been on issues relating to the socio-economic development of the poor, marginalised sections of society and vulnerable groups, such as the aged and children. Several programmes, geared towards social protection, especially in the area of health care services and old age benefits, have thus been instituted. For instance, a health programme tagged Gbomoro aimed at increasing the access of low-income pregnant women to basic health care, and a contributory community-based health insurance scheme tagged Araya, that provides healthcare services to those within the ages of five and 69 who are not covered under the NHIS, have been established by the Ibikunle-led administration in Ogun state. The latter scheme also provides free health care services to vulnerable members of the community, such as pregnant mothers, children under five, and the aged above 70 years of age. ${ }^{87}$ A similar scheme was established in Oyo state by the Ajimobi-led administration in 2014 in four local government areas of the state, including Ibadan South-West, Ibadan South-East, Saki-West and Ogbomoso East local governments and by the Ondo state government in 2011, where about 12 local governments were said to be beneficiaries. ${ }^{88}$ An unemployment assistance scheme, called a Youth Empowerment Scheme, was initiated in 2005 in Kogi state to provide unemployment benefits to over 5000 youths. $^{89}$

While it cannot be disputed that most of the afore-mentioned programmes are laudable in their objectives, the number of beneficiaries still remains an insignificant fraction of the whole, and most of the programmes have not had any visible impact on the suffering masses. In a World Bank Country Programme Portfolio Review for 2013, the country director for Nigeria, Marie Francoise Marie-Nelly, disclosed that about 100 million out of the 1,2 billion people in the world that live in destitution are Nigerians. ${ }^{90}$ "Nigeria's Human Development Index for 2014 was 0.514, which positioned the country in the low human development category and also occupied 152 out of 188 countries and territories considered for that year. ${ }^{91}$ This status was still maintained by the country in $2016 .{ }^{92}$ Although revenue from crude oil increased for decades before it plummeted in

87 S Awoyinfa 'Amosun boosts maternal, child health with incentives' The Punch 30 April 201463.

88 See Anon 'Ondo health care' The Punch 3 November 201111.

89 R Agbana 'Kogi to pay jobless youths N 4500 monthly' The Guardian 29 April 20055.

90 Special Feature 'A nation and its many faces of destitution' The Guardian 28 November 201326.

91 See UNDP Human Development Report (2015) http://www.hdrstats.undp.org/ images/explanations/NGA, pdf (accessed 2 April 2016).

92 L Nwabughiogu 'Nigeria still ranked 152nd in 2016 human development index by UNDP' www.vanguard.com/2016/08/nigeria-still-ranked-152nd-2016-human-dev elopment-index-undp-2/ (accessed 5 February 2017). 
$2015,{ }^{93}$ and Nigeria has had impressive growth performance over the years, which accounted for its being rated as the largest economy on the continent of Africa ahead of South Africa and 26th globally, ${ }^{94}$ this has not translated into prosperity for its people in terms of per capita income and individual living standards as the majority of Nigerians have continued to fall deeper into poverty.

In the same vein, the level of unemployment in the country has worsened over the years. For the first quarter of 2016, the National Bureau of Statistics puts the percentage of the unemployed at 12,1 per cent, up from 10,4 per cent in the fourth quarter of 2015. Underemployment is said to have increased from 18,7 per cent to 19,1 per cent in the same period. ${ }^{95}$ The current figures represent not only wasted personal opportunities and squandered national resources, but also provide an environment where idle hands can create mischief for society.

Furthermore, experience has shown that none of the aforementioned national or state programmes instituted by successive administrations has had a lasting and sustainable positive effect. Most of the programmes have either been completely abrogated or whittled down by successive governments, mostly because there was no legal framework to support them. In this respect it is gratifying to note that Jigawa, a state that has adopted the contributory pension scheme of the PRA 2014, has modified the provisions of the law to include participation of people in the informal sector, such as commercial motorcycle operators, artisans and craftsmen. This state also provides for a disability allowance to the disabled. ${ }^{96}$ Similarly, Ekiti state has specifically enacted the Social Security Law of 2012 according to which free health care services and old age benefits of N $5000,00(\$ 31,64)^{97}$ are provided monthly to persons aged 65 years who are residents of the state. ${ }^{98}$ The programme, which started in 2011, was said to have benefited about 25000 elderly persons by the end of 2014.

$93 \mathrm{Eg}$, in 2007 the African Development Bank put the nation's oil wealth in the preceding 45 years at N84 trillion ( $\$ 666.67$ billion). See Editorial 'Improving the quality of life in Nigeria' The Guardian 8 January 200712.

94 According to the National Bureau of Statistics, after rebasing the economy, the nation's gross domestic product stood at $\$ 510$ bn ahead of South Africa's $\$ 370$ bn. In the first quarter of 2014, real GDP growth was put at 6.21 per cent, which was higher than the corresponding quarter of 2013. See J Onuba \& O Abioye 'Nigeria, now Africa's biggest economy, overtakes S Africa' The Punch 7 April 2014 27.

95 See S Aborisade \& O Adetayo 'Nigeria in volatile situation, says Buhari' The Punch 26 May 20162.

96 Anon 'Jigawa amends contributory pension scheme' The Guardian 22 February 200551.

97 The official average US dollar exchange rate to naira in 2014 was $\mathbb{N} 158$.

98 S Salawudeen 'Ekiti: The journey to welfare state' (2014) http://www. thenationonlineng.net/ekiti-the-journey-to-welfare-state/ (accessed 5 September 2017). 
Moreover, while social security benefits are founded on the notion of individual rights, ${ }^{99}$ which are recognised and protected by the law and may be claimed as an individual entitlement, none of the services or benefits available under any of the afore-mentioned poverty alleviation programmes can as of right be claimed by anyone as they are not anchored in any legislation. There is no gainsaying the fact that legislation is indispensable for the protection of all human rights, including socio-economic rights such as social security. A sound legislative foundation provides a firm basis to protect such rights and to enforce them in case of violations. This is one reason why some of the proposed welfare programmes of the Buhari-led administration should be rooted in legislation validly promulgated by the National Assembly. This will move these programmes from the realm of political commitment to a legal obligation on the part of government and ensure their long-term sustainability. However, there is a need to collaborate with state and local governments for effective implementation.

\section{Conclusion}

The provision of social security is a responsibility owed by the government to all citizens and not to a particular segment of society. 'People', as used in section 14(2)(b) of the 1999 Nigerian Constitution, are not limited to people working in the formal economy but, indeed, applies to all Nigerian citizens. The preferential protection given in Nigerian law on social security to workers in the formal sector cannot be justified in a country professing to uphold the rule of law, which basic components have gone beyond the subordination of every person to the law and separation of powers, to include the guarantee of rights and the principle of social justice. ${ }^{100}$ Social security organised on the basis of rights established through formal wage employment will do nothing for those who cannot earn a living or the poor majority who, at most, have only a marginal place in the formal wage economy. It is evident that the working class in Nigeria constitutes a small percentage of Nigeria's population - the self-employed, the physically and mentally-disabled persons, women outside the labour force caring for children or other dependants, low and irregular earners, such as farmers, artisans and the unemployed who are yet to be provided with any social safety net and who would suffer hardship or require public support or both when contingencies requiring income support arise. As such, paragraph 5 of the ILO Social Protection Floors Recommendation of $2012^{101}$ enjoins member states

99 A 'right' has been defined as 'something that is due to a person by just claim, legal guarantee, or moral principle; a legally enforceable claim that another will do or will not do a given act; a recognised and protected interest, the violation of which is a wrong'. See BA Garner Black's law dictionary (2009) 1436.

100 Sec 14(1) of the 1999 Nigerian Constitution provides that '[t]he Federal Republic of Nigeria shall be a state based on the principles of democracy and social justice'. 
to establish social protection floors comprising a basic social security guarantee that includes access to essential health care and basic income security for children and for persons who are unable to earn a sufficient income, particularly in cases of sickness, unemployment, maternity and disability as well as for older persons. ${ }^{102}$ Therefore, there is a dire need for the due implementation of the right to social security in the country in order to guarantee the necessary support to all, not only in the event of loss of earning, but also against all forms of eventualities that could lead to widespread economic deprivation.

In this respect it is important to fully embrace the concept of social and economic rights which include not only the right to economic welfare and security, but also the right to share to the full in the social heritage and to live the life of civilised beings, according to the standards prevailing in society. ${ }^{103}$ The cardinal objective of socioeconomic rights is distributional equity, that is, the increasing diffusion of benefits of growth to the population, which is the fulcrum of social security. ${ }^{104}$ Thus, in addition to the legislative fiat, which the Nigerian Supreme Court has ruled could be used to enforce the provisions of Chapter II of the Nigerian Constitution, the Nigerian courts, through a pro-active interpretation of the relevant constitutional provisions, in appropriate cases, can make the rights contained in the Directive Principles justiciable rights. The approach of the Ghanaian and Indian courts to Directive Principles of State Policy is commendable and should be emulated by Nigeria to further the ends of liberty, equity and justice in Nigeria and to ensure that government performs its obligation of providing social security to the people. ${ }^{105}$ What is generally required is for the Nigerian policy makers

101 http://www.ilo.org/dyn/normlex/en/f?p=NORMLEXPUB:12100:0::NO::P12100_ ILO_CODE:R202 (accessed 6 September 2017).

102 See also, eg, the Yaounde Tripartite Declaration on the Implementation of the Social Protection Floor 2010 which, inter alia, enjoins member states to promote social security mechanisms adapted to the informal economy (n 16 above).

103 TH Marshall Sociology at the crossroads (1963) 74.

104 J Donnelly 'Repression and development: The political contingency of human rights' in D Forsythe (ed) Trade-offs, human rights and development: International views (1989) 307; see also CJ Friedrich The philosophy of law in historical perspectives (1963) 21; L Lloyd \& MDA Freeman Lloyd's introduction to jurisprudence (1985) 566.

105 The approach of the Indian courts to Fundamental Objectives and Directive Principles, it has been noted, should commend itself to the Nigerian judiciary, not only because its concept of Directive Principles originated from the Indian Constitution, but more so because of the striking similarity in prevailing socioeconomic conditions in both countries, particularly in terms of oligarchic insensitivity to human suffering, wanton deprivations and widening disparity in life expectancy between the less-privileged and affluent individuals. See O Nnamuchi 'Kleptocracy and its many faces: The challenges of justiciability of the right to health care in Nigeria' (2008) 52 Journal of African Law 110. 
to muster enough political will to commit a sufficient budgetary allocation to the institutionalisation and 'progressive realisation' 106 of a viable all-inclusive social security scheme in our laws. If there is no public or constitutional provision compelling government to provide social services, such as social security, the only measure of the utility of such services, presumably, would be their ultimate economic cost. There is a compelling need, therefore, to establish non-contributory tax-financed schemes that would provide a social safety net to those in the informal sector. Also, as a crucial step towards ensuring the due implementation of the right to social security in Nigeria, it is essential for Nigeria to ratify and domesticate key ILO conventions on social security, especially the Social Security (Minimum Standards) Convention 102 of 1952 which five other African countries, namely, the Democratic Republic of the Congo, Libyan Arab Jamahiriya, Mauritania, Niger and Senegal have ratified.

It is indisputable that the only viable option for the immediate and rapid socio-economic emancipation in Nigeria and the renaissance of virtue and patriotism lies in the implementation of the right to social security with seriousness of purpose. To delay this will be at the peril of the country.

106 See art 2(1) of the ICESCR. The 'progressive realisation' formulation, it has been explained, connotes that the state's obligation is dynamic and it should increase over time. It is a recognition of the fact that the full realisation of rights, such as the socio-economic rights contained in the ICESCR, will generally not be able to be achieved in a short period of time. Thus, a state may not merely assert a lack of available funding as justification for doing nothing to advance a social right, such as social security. See Christiansen (n 35 above); M Ssenyonjo 'Reflections on state obligations with respect to economic, social and cultural rights in international human rights law' (2011) 15 International Journal of Human Rights 969977.

107 Social protection http://www.social-protection.org/gimi/gess/ShowTheme.do? tid=722 (accessed 6 September 2017). 